\title{
Nueva Ecija's Philippine Lime (Citrofortunella microcarpa) Agribusiness Industry: Marketing Disputes and Economic Outlooks
}

\author{
Ma. Florisa Quijano, Ph.D., Gerald Quijano, Ph.D., Rowell Diaz, MBA \\ Nueva Ecija University of Science and Technology, Fort Magsaysay Campus. quijanomaflorisa@gmail.com \\ Nueva Ecija University of Science and Technology, Fort Magsaysay Campus. geraldagustin20@yahoo.com \\ Nueva Ecija University of Science and Technology, San Isidro (Tabon) Campus. rowell.diaz@neust.edu.ph
}

Abstract: Philippine Lime or Calamansi is considered one of the Philippine high-value crops in Nueva Ecija province. This article presents some issues and problems of the calamansi industry in terms of marketing. The study used a descriptive survey of 56 farm-owners or calamansi growers. Findings revealed that lime production could be a stable income source if the growers can provide the necessary production inputs on a sustainable basis. Calamansi farmers in the province some often confronted with the following problems: the high cost of farm inputs, price fluctuations, price manipulation of big-time traders, and other intermediaries. The study also found out that the existing actors in the chain were limited to growers, laborers, agri-supply shops, nursery owners, intermediaries, and traders. In terms of trading, there is a high degree of competition among traders in the market. The findings and results from this study may have important factors in developing and designing effective agricultural marketing program and startegic development plan by the authorities in the region.

Keywords: Philippine Lime, calamansi, agribusiness, marketing, Nueva Ecija.

\section{INTRODUCTION}

Nueva Ecija had the largest share of calamansi production in Central Luzon (Calamansi Production Guide, 2018). There were about eighteen (18) municipalities engaged in calamansi farming in 2014. The province's top growers included San Leonardo, Cabanatuan City, Palayan City, Cabiao, and Peñaranda. A total of 756, 136 trees were planted in the province, of which 684, 615 already bore fruits. Approximately 1,481 farmers grow the fruit in the province, and some 1,200 hectares of land are cultivated for calamansi production and farming. Agricultural industry in developing countries is undergoing profound, fast-moving changes (Soundarrajan and Vivek, 2015). An established processing plant operated by a group of growers through a cooperative is evident only in Palayan City. Cooperatives have brought significant contributions to uplift many individuals' lives and resolve problems related to marketing, production, and financial (Mina, 2019). Diaz et al, 2020 on their paper discussed that a strong financial transaction is an important factor in organizational triumph and sustainability operation is through the assistance of the Department of Trade and Industry and the Department of Agriculture (DA). Calamansi growers in Cabanatuan City are still obtaining the approval of DA to start the operation of a processing plant in the area.

Based on the data mentioned above, it is worth knowing the possible gaps and constraints in developing calamansi production in the province limiting its capacity for growth and expansion and making it still lagging in production in other competitive regions. This situation has inspired the researcher, who is also a farmer and a native of Nueva Ecija to engage in an agribusiness 
research such as this one. Today, the citrus is still considered a high-value commercial crop, and the government had taken steps to enhance and improve the productivity of the industry in the country (Libunao and Libunao, 2003)

\section{Philippine Lime or Calamansi Industry in Nueva Ecija}

Calamansi growing in Palayan City got a big boost in popularity and economic recognition. Several calamansi farms have recently produced citrus juice in commercial quantities, which slowly gained patronage from many first-class eateries in the city, elsewhere in the province, and even in Metro Manila areas. With this, the DTI has granted the Palayan City Calamansi Growers Association (PCCGA) with a P2.2-million juice extraction machinery under its Shared Service Facility program.

Since agricultural production has become a source of livelihood in the province of Nueva Ecija, it cannot deny that the industry also has existing problems and constraints. The socio-economic, demographic, and biological factors contributing to these negative effects are constitute the most significant disadvantages faced by agriculture (Topçu, 2008). Calamansi production for the third quarter of 2018 decreased by $2.1 \%$, from 54.70 thousand metric tons (MT) in the same quarter of the year 2017 to 53.56 thousand metric tons (PSA, 2018). This specific situation triggered the researcher to have the interest to investigate the agricultural economic potential of the calamansi industry in Nueva Ecija as one of the sustainable province in terms of agriculture. The definition of sustainable agriculture can also be understood from a social point of view as the ability to respond to the global demand for production (Tirivayi et al. 2016). Through this study, the researcher can provide data that may reveal the actual situation of calamansi industry in Nueva Ecija, which would aid her in determining its potential. Doing so would significantly help empower calamansi producers and farmers and uphold viable improvement and enhance its competitiveness.

\section{Opportunities for Philippine Lime or Calamansi Industry}

A "value chain" study of calamansi was carried out to beef up output and some 170 metric tons (MT) to export fresh and processed fruits per year and shipped to Hongkong, UAE, and Saudi Arabia. "The value chain analysis or VCA describes the activities that the organization performs and links them to the organization's competitive position. It encompasses the activities within and around an organization and relates them to an analysis of the competitive strength of the organization" (Porter, 2015) The country's export of calamansi ranged from 20-35 MT in 2008, with an average annual export of 29.5 metric tons MT in fresh fruits. A value chain advantage may be found in turning fresh fruits into value-added processed goods (bottled juice, puree). A total of 144 metric tons MT of calamansi juice and concentrate was exported to Hongkong, United Arab Emirates, and Saudi Arabia in 2013. In Italy, in the range of time between 1991 and 2013, since the abatement of phytosanitary barriers (1992) up to today (Chinnici et al. 2013), the investments in citrus fruits farming have reduced from about 182 thousand hectares to 152 thousand hectares with a reduction of over $16 \%$. Involvement in different marketing channels may allow farmers to maximize profits and reduce overall risks (Kim et al. 2014) 
The organization of Southeast Asian Regional Center for Graduate Study and Research in Agriculture (SEARCA) reported that the country's calamansi export ranged from 20-35 metric tons in 2008-2013 with an average yearly export of 29.5 MT in fresh fruits. Calamansi was in great demand in abroad. In South Korea, for instance, it was among the latest food fads. The Korean market for food and beverage was a very competitive one. The Korean market tried to differentiate itself by giving new products in the market. Calamansi has reached the stage where it was too different from other lemon products. A lot of Korean tourists who came to the Philippines were already familiar with calamansi.

\section{Problems Encountered in the Lime Industry}

In the Philippines, the local supply of citrus was insufficient to meet local demand. This has resulted in a high occurence of pests and diseases, inadequate management of orchard, and low acceotance of improved management practices, among many other factors. Meanwhile, the shortage was filled with imports from China, which outcompeted, both cost-wise and quality-wise, locally produced fruits (2017). There were gaps and constraints in the calamansi industry that limited its potential to increase income and generated much-needed employment for the calamansi-growing communities (dispatchtoday.com.ph, 2018). The Philippine Calamansi Association, Inc. (PCAI) recently said that research and development (R\&D) programs should address the declining production of calamansi in the country. PCAI stakeholders emphasized that R\&D initiatives should also focus on the lack of supply of quality seedlings and the declining fresh calamansi production due to aging trees, shifting to production of other high-value crops, and rampant conversion of calamansi farms into residential uses. Other constraints included: high incidence of pests and diseases; the declining volume of production; huge postharvest losses; limited access to market; inconsistent quality of processed calamansi products; low prices during peak season; and lack of resources, skills, knowledge, and experience in collective marketing among calamansi farmers.

However, in the past decades, an oversupply of fresh calamansi produce in the market during peak production periods caused plummet and fruit prices to rot in many farms. Farmers have been discouraged from maintaining their calamansi trees and shifted to producing other fruits. Areas devoted to calamansi production gradually declined and the likely threat of continuous decline was foreseen in succeeding years. The farmers' most pressing problem was the seasonal supply of the calamansi fruits that caused a market glut during peak season, which resulted in its low price. During this period, the price ranged from P5.00 - P8.00 per kilogram. Thus, farmers opted not to harvest their fruits because labor costs and transportation were unlikely be recovered. Given this situation, there was a need to explore different marketing possibilities for calamansi, both in fresh and processed forms. In a highly volatile, competitive environment, successful business entities do not just add value but reinvent themselves through interactive strategy, specifically by reconfiguring roles, relationships, and structures (Normann and Ramirez, 2000) 


\section{MATERIALS AND METHODS}

This analysis used a descriptive type of research. A descriptive type of research is used to obtain information concerning the current status of conditions in a situation. The study described the calamansi industry using value chain analysis focusing on input provision, production, postproduction, marketing, and cost and return analysis. Problems and constraints in the industry were also included. The analysis results would be then the bases in proposing a strategic action plan for the calamansi industry in Nueva Ecija. The researcher sent a sample quota of at least ten (10) respondent-growers in each municipality. The researcher distributed the survey-questionnaire on the different barangays of the top five calamansi producing cities and municipalities to reduce bias and subjectivity.

Table 1.

Distribution of Respondents by Cities and Municipalities

\begin{tabular}{cc}
\hline Respondents & Sample \\
\hline 1. Calamansi Growers & 10 \\
San Leonardo & 10 \\
Cabanatuan City & 10 \\
Palayan City & 10 \\
Cabiao & 10 \\
Peñaranda & 6 \\
2. City/Municipal/Provincial Agriculturists & 56 \\
Grand Total & $\mathbf{5 6}$ \\
\hline
\end{tabular}

\section{Research Instruments}

The researcher used a survey-questionnaire to collect the necessary data. The instrument was a structured questionnaire supported by an unstructured interview to bring about additional information and check the respondents' consistency of responses to the data gathering instrument.

\section{RESULTS AND DISCUSSION}

Marketing. Marketing is the last phase in the value chain, including selling strategies and modes of payments practiced by buyers. Selling at Farmgate Price/kilo. Growers sell their fruits right after the harvest, especially if the farmgate price is attractive and good enough to recover their expenses in the entire production process. Marketing channel selection is one of the most important decisions a farmer can make and has a significant effect on the profitability of farm businesses (Liao, Chang, He, \& Saeliw, 2017).

The farmgate price per kilo of calamansi fruit in the last two years showed that during peak months (June to October 2018-2019), the fruit prices were in their lowest averages to P15.2/kilo to P8.40/kilo. According to the informant in the Provincial Agriculturist Office of the province, seventy percent $(70 \%)$ of the calamansi fruits of Nueva Ecija were produced during peak season 
(June to October) when prices were very low. This can be attributed to the natural characteristic of calamansi tree that still bore fruits during rainy season even with less farm inputs. Over the last decade, citrus fruit farming, at the international level, has shown an upward trend that has changed the conventional supply scenarios, with the trade of goods from all parts of the world, thanks to the progressive abolition of tariff barriers, (Scuderi and Sturiale, 2016)

As claimed by the respondents during the lean season (November to May), prices began to rise slowly and typically hit the highest levels during March, April, and May. However, this was not always the case. Like any industry in the event of calamities, pest and disease infestation, and unpredictable climatic conditions that affected the production of calamansi, prices rose as well even during June to October due to lower production volume. Apart from the supply factor, prices were often influenced by demand indicators. In the case of Nueva Ecija, if the time came for the production of calamansi to flourish and be able to convert the fruit into other valuable products such as juice, jam, oil, soap, and gel, the demand for the product automatically increased, thus achieving price stability. This is called the value-added principle on products. The term "valueadded" describes the enhancement an enterprise gives its product or service before offering it to customers. It can be considered an extra special feature added by the enterprise or producer to increase a product's value. By doing so, an oversupply of agricultural production in farms would be converted to other desirable goods at higher prices until the equilibrium of demand and supply for agricultural output is reached again, thus stabilizing prices. Table 28 presents the year-round farmgate price per bag of calamansi based on respondents' data for the last two years.

Table 28.

Average Farmgate Price per Kilo of Calamansi from 2017-2019

\begin{tabular}{|c|c|c|c|c|c|c|c|c|c|c|c|c|c|c|}
\hline \multirow{3}{*}{\multicolumn{2}{|c|}{ City/Municipality }} & \multirow{3}{*}{ Year } & \multicolumn{12}{|c|}{ 12-Month Period } \\
\hline & & & \multicolumn{5}{|c|}{ PEAK SEASON } & \multicolumn{7}{|c|}{$\begin{array}{l}\text { LEAN SEASON } \\
\text { LEASON }\end{array}$} \\
\hline & & & Jun & Jul & Aug & Sep & Oct & Nov & Dec & Jan & Feb & Mar & Apr & May \\
\hline \multirow{18}{*}{$\begin{array}{c}\text { Prices } \\
(2017 \\
- \\
\text { 2019) } \\
\text { in } \\
\text { Php }\end{array}$} & \multirow{3}{*}{$\begin{array}{c}\text { San } \\
\text { Leonardo }\end{array}$} & 2019 & P16 & P16 & P8 & P8 & $\mathrm{P} 15$ & $\mathrm{P} 15$ & P20 & P33 & $\mathrm{P} 30$ & P33 & $\mathrm{P} 60$ & $\mathrm{P} 23$ \\
\hline & & 2018 & 15 & 15 & 10 & 8 & 26 & 26 & 30 & 30 & 30 & 35 & 65 & 20 \\
\hline & & 2017 & 15 & 16 & 10 & 8 & 25 & 25 & 28 & 30 & 30 & 30 & 60 & 20 \\
\hline & \multirow{3}{*}{ Cabanatuan } & 2019 & 16 & 16 & 8 & 8 & 15 & 15 & 18 & 35 & 35 & 30 & 65 & 23 \\
\hline & & 2018 & 15 & 15 & 10 & 8 & 30 & 30 & 30 & 35 & 35 & 35 & 60 & 20 \\
\hline & & 2017 & 15 & 15 & 10 & 8 & 25 & 25 & 30 & 30 & 35 & 35 & 60 & 20 \\
\hline & \multirow{3}{*}{ Palayan } & 2019 & 16 & 16 & 8 & 8 & 15 & 15 & 20 & 35 & 35 & 30 & 65 & 23 \\
\hline & & 2018 & 15 & 15 & 10 & 10 & 25 & 25 & 30 & 30 & 30 & 35 & 65 & 20 \\
\hline & & 2017 & 15 & 15 & 10 & 10 & 25 & 25 & 30 & 30 & 30 & 35 & 65 & 20 \\
\hline & \multirow{3}{*}{ Cabiao } & 2019 & 16 & 16 & 10 & 8 & 15 & 15 & 15 & 30 & 30 & 35 & 65 & 25 \\
\hline & & 2018 & 16 & 16 & 10 & 8 & 30 & 30 & 30 & 30 & 35 & 35 & 65 & 25 \\
\hline & & 2017 & 15 & 15 & 10 & 8 & 30 & 30 & 30 & 30 & 30 & 35 & 65 & 25 \\
\hline & \multirow{4}{*}{ Peñaranda } & 2019 & 16 & 16 & 8 & 8 & 15 & 15 & 15 & 33 & 30 & 33 & 60 & 23 \\
\hline & & 2018 & 15 & 15 & 10 & 8 & 26 & 26 & 30 & 30 & 30 & 35 & 65 & 20 \\
\hline & & 2017 & 15 & 15 & 10 & 8 & 25 & 25 & 30 & 30 & 30 & 35 & 60 & 23 \\
\hline & & 2019 & $\begin{array}{c}16 . \\
0\end{array}$ & 16.0 & 8.4 & 8.0 & 15.0 & 15.0 & 16.6 & 33.2 & 32.0 & 32.2 & 63.0 & 23.4 \\
\hline & \multirow[t]{2}{*}{ Average } & 2018 & $\begin{array}{c}15 . \\
2\end{array}$ & 15.2 & 10.0 & 8.4 & 27.4 & 27.4 & 30.0 & 31.0 & 32.0 & 35.0 & 64.0 & 21.0 \\
\hline & & 2017 & $\begin{array}{c}15 . \\
0\end{array}$ & 15.2 & 10.0 & 8.4 & 26.0 & 26.0 & 29.6 & 30.0 & 31.0 & 34.0 & 62.0 & 21.6 \\
\hline
\end{tabular}

Sources: Data is from the responses of the calamansi growers in the top 5 producing cities/municipalities of Nueva Ecija 
As can be seen from Table28, in the last months of 2019 (November-December), growers expected that prices will continue to rise during the Christmas season, when demand for fruit was high, just as they did not in the previous year. There was an average price increase of $\mathrm{P} 5.00$ but was still lower than what was anticipated. In 2018, from P 10.00 average price, it increased to P 26.00.00 and P 30.00 in November and December. Based on interviews conducted, growers said that in their last five years of farming, the price of calamansi usually increased during the same season, but 2019 was an exception. A possible explanation for this was the increase in production relative to the previous quarter. According to the Philippine Statistics Office, calamansi production reached 66.76 thousand metric tons in the last quarter of 2019 . It was $24.6 \%$ higher than the same quarter level of 53.56 thousand metric tons in 2018. This added the fact that despite no calamity record, production still decreased.

Table 28 also pointed out slight price differences in the five (5) localities. Cabanatuan and Palayan City had the same prices in most of the year while Cabiao, San Leonardo, and Peñaranda were most likely similar. The three (3) municipalities did not just cater to markets in Cabanatuan and Sta. Rosa, but also, they sold their commodities in San Fernando, Pampanga. The growing industry of calamansi in Tarlac also affected the market supply in the past two years. Hence, it was expected to be one of the province's leading competitors in quality and production in the coming years. Conceivably, this brought changes in demand and price. With this, it can be concluded that the primary factor in the price changes is still the demand and supply factor, and calamansi production is no exception.

Price manipulations, especially by intermediaries, could trigger a disequilibrium in the value chain. With the interviews conducted, the "sakadora system" also played a big role in the price of the fruit. As a selling practice, growers in the said localities had already established distribution channels in the disposal of their commodity. The "suki", more popularly known as "kasadora" sold the fruit to agents and traders in Divisoria, Pasig and San Fernando. With the researcher's interview of some "kasadoras" in Sangitan Market, according to them, they usually added P 40.00- P 60.00 for trading one (1) red bag of calamansi. They added a high as P 100.00 per bag during the lean season, but their commission just ranged from P 10.00-P 20.00 per bag for peak season when the price was low. They manipulated the prices, especially during peak season when production was higher, and the demand was lower.

One disadvantage in calamansi farming is that the growers do not have an option to wait for the price to increase since the fruit is subject to decay, unlike palay and onion. The only way to preserve the fruit is to process or convert it to other valuable products such as juice, soap, and oil. The fruit yields a higher value in times of lower agricultural/raw prices through the manufacturing concept. In Cabiao, some growers opted to go into the "rolling system" and sold their fruits in a retail price higher than the farm gate price to augment their income.

Distribution Channel. An effective and sufficient marketing system is a prerequisite for agricultural diversification, for better prices for farmers and for the availability of competitively priced goods to consumers. Due to the increased demand of consumers for local foods and growing concerns regarding food safety and health, direct marketing of agricultural products has become increasingly popular (Curtis 2010; Timmons and Wang 2010). However, the volume of products sold through direct marketing is usually low and farmers have to face the risk of unsold products 
(Morgan and Alipoe 2001). Farmers and traders perform several marketing practices in moving the products from one point to another (BAS, 2003). The major practices and functions in the calamansi industry include the manner of procurement and distribution, mode of payment, and geographic flow of commodity.

Table 29.

Calamansi Buyers, Mode of Payment and Mode of Distribution

\begin{tabular}{|c|c|c|c|c|c|c|c|c|c|c|c|c|c|}
\hline \multirow[t]{2}{*}{ Description } & \multirow{2}{*}{$\frac{\text { Items }}{\text { Traders }}$} & \multicolumn{2}{|c|}{$\begin{array}{c}\text { San } \\
\text { Leonardo }\end{array}$} & \multicolumn{2}{|c|}{ Cabanatuan } & \multicolumn{2}{|c|}{ Palayan } & \multicolumn{2}{|c|}{ Cabiao } & \multicolumn{2}{|c|}{ Pẽ̃aranda } & \multicolumn{2}{|c|}{ Total } \\
\hline & & 9 & 90.00 & 8 & 80.00 & 6 & 60.00 & 8 & 80.00 & 8 & 80.00 & 39 & 78.00 \\
\hline \multirow{3}{*}{ Buyers } & $\begin{array}{l}\text { Cooperative- } \\
\text { Processor }\end{array}$ & 0 & 0.00 & 0 & 0.00 & 2 & 0.00 & 0 & 0.00 & 0 & 0.00 & 0 & 2.00 \\
\hline & $\begin{array}{l}\text { Retail } \\
\text { Market }\end{array}$ & 1 & 10.00 & 2 & 20.00 & 2 & 30.00 & 2 & 20.00 & 2 & 20.00 & 10 & 20.00 \\
\hline & Total & 10 & 100.00 & 10 & 100 & 10 & 100.00 & 10 & 100.00 & 10 & 10 & 50 & 100.00 \\
\hline \multirow{4}{*}{$\begin{array}{l}\text { Mode of } \\
\text { Payment }\end{array}$} & Cash & 8 & 80.00 & 9 & 90.00 & 7 & 70.00 & 8 & 80.00 & 8 & 80.00 & 40 & 80.00 \\
\hline & Consignment & 0 & 0.00 & 0 & 0.00 & 0 & 0.00 & 0 & 0.00 & 0 & 0.00 & 0 & 0.00 \\
\hline & Both & 2 & 20.00 & 1 & 10.00 & 3 & 30.00 & 2 & 20.00 & 2 & 20.00 & 10 & 20.00 \\
\hline & Total & 10 & 100.00 & 10 & 100.00 & 10 & 100.00 & 10 & 100.00 & 10 & 100.00 & 50 & 100.00 \\
\hline \multirow{4}{*}{$\begin{array}{c}\text { Mode of } \\
\text { Distribution } \\
\text { to Buyers }\end{array}$} & Delivered & 0 & 0.00 & 2 & 20.00 & 0 & 0.00 & 2 & 20.00 & 0 & 0.00 & 4 & 8.00 \\
\hline & Picked-up & 0 & 0.00 & 0 & 0.00 & 0 & 0.00 & 1 & 10.00 & 0 & 0.00 & 1 & 2.00 \\
\hline & Both & 10 & 100.00 & 8 & 80.00 & 10 & 10.00 & 7 & 70.00 & 10 & 100.00 & 45 & 90.00 \\
\hline & Total & 10 & 100.00 & 10 & 100.00 & 10 & 100.00 & 10 & 100.00 & 10 & 100.00 & 50 & 100.00 \\
\hline
\end{tabular}

The table above shows the usual buyers of the calmansi produce from the farm. From the farm level, the growers typically delivered their produce to the trading center. In the case of Nueva Ecija, most of the growers revealed that it was Sangitan Market, which serves as the trading center for good. It is where the selling agents or the "sakadoras" can be found. From the Sangitan Market, the "sakadoras" made negotiations with traders from Bulacan and NCR such as those from Divisoria and Pasig. In the case of Cabiao growers, Pampanga traders were also buyers of the fruit. The traders made up $78 \%$ of the calamansi buyers in the province.

Aside from traders, retail market in the producing localities were also buyers of the goods. These were the agricultural sector and vegetable sellers found in the local markets. The agricultural industry, particularly in developing countries, has an important role to play in terms of the capital required for other sectors, by means of skilled labour, the supply of raw materials to industry, exports and their contribution to national income and the provision of employment opportunities(Bayramoglu et al., 2018).

In the case of Palayan City, where an existing cooperative is now engaged in processing, growermembers sell part of their harvest to the cooperative. The calamansi juice produced by the processing plant is sold primarily to government agencies in the area and small establishments with the Department of Trade and Industry's assistance. The growers usually paid in cash in terms of payment, although there were times, particularly during peak season, that growers were paid on a consignment basis. They needed to wait until the selling agents sold the fruit. 


\section{Problems Encountered in Marketing}

Table 35 presents the problems of calamansi growers in marketing their calamansi produce.

Table 35

Problems on Marketing Encountered by Calamansi Growers

\begin{tabular}{|c|c|c|c|c|c|c|c|c|c|c|c|c|}
\hline \multirow{2}{*}{$\begin{array}{c}\text { Problems in Marketing } \\
\text { Items }\end{array}$} & \multicolumn{2}{|c|}{$\begin{array}{c}\text { San } \\
\text { Leonardo }\end{array}$} & \multicolumn{2}{|c|}{ Cabanatuan } & \multicolumn{2}{|c|}{ Palayan } & \multicolumn{2}{|c|}{ Cabiao } & \multicolumn{2}{|c|}{ Peñaranda } & \multirow[t]{2}{*}{$\begin{array}{c}\text { Ave. } \\
\%\end{array}$} & \multirow[t]{2}{*}{ Rank } \\
\hline & $f$ & $\%$ & $\mathrm{f}$ & $\%$ & $\mathrm{f}$ & $\%$ & $f$ & $\%$ & $F$ & $\%$ & & \\
\hline $\begin{array}{l}\text { Low price due to low } \\
\text { quality of produce and } \\
\text { oversupply }\end{array}$ & 8 & 80 & 8 & 80 & 7 & 70 & 8 & 80 & 7 & 70 & $76 \%$ & 5 \\
\hline $\begin{array}{l}\text { Poor farm to market } \\
\text { roads }\end{array}$ & 5 & 50 & 7 & 70 & 8 & 80 & 4 & 40 & 5 & 50 & $58 \%$ & 7 \\
\hline $\begin{array}{l}\text { Price manipulation of } \\
\text { trading agents } \\
(\text { sakadora })\end{array}$ & 9 & 90 & 9 & 90 & 9 & 90 & 8 & 80 & 9 & 90 & $88 \%$ & 1 \\
\hline $\begin{array}{l}\text { Price manipulation of } \\
\text { big time traders } \\
\text { Frequent price }\end{array}$ & 8 & 80 & 9 & 90 & 8 & 80 & 8 & 80 & 8 & 80 & $82 \%$ & 3 \\
\hline $\begin{array}{c}\text { fluctuation/unstable } \\
\text { prices }\end{array}$ & 9 & 90 & 9 & 90 & 8 & 80 & 8 & 80 & 8 & 80 & $84 \%$ & 2 \\
\hline $\begin{array}{l}\text { Too many competitors } \\
\text { during peak season }\end{array}$ & 8 & 80 & 7 & 70 & 8 & 80 & 8 & 80 & 8 & 80 & $78 \%$ & 4 \\
\hline $\begin{array}{c}\text { Absence of permanent } \\
\text { buyer }\end{array}$ & 7 & 70 & 7 & 70 & 7 & 70 & 7 & 70 & 7 & 70 & $70 \%$ & 6 \\
\hline
\end{tabular}

Price manipulation by trading agents or "sakadoras" remained a problem they encountered in marketing (88\%). Frequent price fluctuation (84\%), price manipulation of big-time traders $(82 \%)$, and numerous competitors during peak season $(78 \%)$ were the foremost encountered by calamansi growers. Other problems like low price due to a too low quality of produce and oversupply (76\%), absence of permanent market buyer (70\%), poor farm to market roads $(58 \%)$, and delayed payment of goods (56\%) ranked fifth, sixth, seventh and eight respectively.

The "sakadora scheme" is a long-standing marketing method for the disposal of calamansi from farms. Such "sakadoras" served as selling agents in the trading of goods on the market. Without their intermediation, it is difficult for growers to sell their commodity to reach the market. The scheme might be favorable to them because of the cost of transporting the goods but was susceptible to price manipulation. Only large farmland owners who operated 10 hectares or more in the province had access to large-scale traders, freed them from the middleman network.

Another marketing problem cited by the growers was the price manipulation of big-time traders. Even if the commodity had a short consumable period that could not be subjected to hoarding, price manipulations were still big. As experienced by growers, Nueva Ecija calamansi fruits could not directly compete with Oriental Mindoro and Davao regions' harvest in terms of fruit size and quality. Thus, their produce prices were still bargained at the lowest price possible.

Fluctuation in price was also one of the serious marketing problems experienced by growers. The evolution of the social-economic system, the orientation changes of the agricultural policy, especially in the European Union, the market globalization, the evident asymmetries of 
costs within the sector among the different countries at a different level of development and much more, have contributed to eroding of the primary role of citrus fruits farming in the island, causing fluctuating income levels with the unevenness both among different species and different areas of cultivation (Carra et al. 2014; Tudisca et al. 2014; Scuderi et al. 2015a). As cited by them, this resulted from basic market aggregates, supply, and demand. Farmgate price of calamansi was mainly affected by the level of production that caused the price fluctuations.

In the calamansi producing municipalities in the province, growers also experienced problems in their community's number of competitors. According to them, this problem was evident during peak season when most of the growers simultaneously sold their harvests in the market. The absence of permanent buyer was occasionally evident during peak season because of large production.

Another problem was the farm to market roads for calamansi growers whose farms were located in far-flung barangays as in Popolon and Aulo in Palayan City. Production categories in calamansi farming can be divided into two (2) types. The first is low production, which means a low amount of fruit harvest and typically happens during the lean season from November to May. On the other hand, high production means a high amount of fruit harvest and generally occurs during the peak season from July to October. A calamansi grower is prone to agricultural problems during low or high production for the whole year including the labor cost. The worker turnover rate was high since they were underpaid (Mina etal, 2019).

\section{CONCLUSION}

The number of the harvest of calamansi growers was greatly affected by pest infestation and bad weather conditions. In the last two years, the farmgate price of calamansi showed the same pattern with moderate differences comes November and December of 2019 compared to the previous year. Its peak season was from June to October, and the lean season was from November to May. Proper cultural management and timing was an effective tool to increase the grower's farm income.

The top problems of the calamansi growers were the high cost of fertilizers, insecticides and fungicides, price manipulation of intermediaries (kasadoras) and big time traders, frequent price fluctuation, and spoilage wastage during peak season. The government may direct concerned government agencies to intensify research and development to improve new varieties, varietal improvement through biotechnology, and accreditation of nurseries. The government may provide more support facilities such as ports, farm-to-market roads, and cold chain systems. The agricultural sector's governing agencies may consider the export potential of the calamansi produce in Nueva Ecija to help the growers uplift their livelihood.

\section{REFERENCES}

Baniqued, C.A. (2000): Status of disease management of citrus in the Philippines: Focus in the Cordillera, 111-117. In: A.B. Molina, V.N. Roa, J. Bay-Petersen, A.T. Carpio, and J.E.A. Joven (eds.). Managing banana and citrus diseases: Proceedings of a regional workshop on disease 
management of banana and citrus through the use of disease-free planting materials held in Davao City, Philippines, 14-16 October 1998. International Network for the Improvement of Banana and Plantain-Asia and the Pacific Network, Los Baños, Laguna, Philippines.

Bayramoglu, Z., Oguz, C., Karakayaci, Z. \& Arısoy, H. (2018): Identification of the income level needed for agricultural enterprises to achieve economic sustainability, Economic ResearchEkonomska Istraživanja, 31:1, 510-520, DOI: 10.1080/1331677X.2018.1438908

Carra G., Peri I., Scuderi A. (2014): Euro-mediterranean agricultural trade agreement: which real impact on the EU citrus production? Quality - Access to Success, 15: 111-116.

Curtis K. (2010). Direct marketing local foods: Food safety considerations. All Current Publications, Paper 99, Utah University State. Available at http://digitalcommons. usu.edu/extension_curall/99.

Diaz, R.; De Leon, C.; Vitug, E.; Linsangan, L. (2020): Exploration of financial management operation of political and non-political student organization: A basis for propose policy development. Preprints, 2020120303: (doi: 10.20944/preprints202012.0303.v1).

Chinnici G., Pecorino B., Scuderi A. (2013): Enviromental and economic performance of organic citrus growing. Quality - Access to Success, 13: S1.

Kim M., Curtis K., Yeager I. (2014): An assessment of market strategies for small-scale produce growers. International Food and Agribusiness Management Review, 17: 187-204.

Liao P.-A., Chang H.-H., He J., Saeliw K. (2017): Diversifi cation of marketing strategies among small farms: empirical evidence from family farms in Taiwan. Agric. Econ. - Czech, 63: 493-501.

Libunao, V.M., and L.P. Libunao. (2000): Survey on the supply and demand of selected high value citrus fruits in Region I. Res. J. Agr. Dept. DMMMSU (2000): 89-100.

M. Porter, (1985): Competitive advantage: Creating and sustaining superior performance", New York, Simon and Schuster.

Mina, J.C, Subia, G.S and Ermita P.P (2020): Value chain analysis of slipper industry in the Footwear Capital of the North. Int. J. Sup. Chain. Mgt., 9(5):178.

Mina, J.C. (2019): Attainment of cooperative objectives and the performance of officers in performing their Management Functions: A Case of Cooperatives in Gapan City, Nueva Ecija. International Journal of Advanced Engineering, Management and Sciences, 5(11): 577-579.

Morgan T., Alipoe D. (2001): Factors affecting the number and type of small-farm direct marketing outlets in Mississippi. Journal of Food Distribution Research, 32: 125-132. 
Normann, R., and R. Ramirez. (2000): From value chain to value constellation: Designing interactive strategy: 185-219. In: Harvard Business School Press (comp.). Harvard business review on managing the value chain. Harvard Business School Press, Boston, MA.

Scuderi A., D’Amico M. (2015a): Evolution of development models of Italian organic citrus. Acta Horticulturae, 1065: 1877-1888.

Scuderi A., Sturiale L. (2016): Multi-criteria evaluation model to face phytosanitary emergencies: The case of citrus fruits farming in Italy. Agric. Econ. - Czech, 62: 205-214

Timmons D., Wang Q. (2010): Direct food sales in the United States: Evidence from state and county-level data. Journal of Sustainable Agriculture, 34: 229-240.

Tirivayi N., Knowles M., Davis B. (2016): The interaction between social protection and agriculture: A review of evidence. Global Food Security, 10: 52-62.

Topçu, Y. (2008): Effective factors' analysis on willingness to utilize from farmers' agricultural support policies: The case study of Erzurum province. Akdeniz University Journal of Agricultural Faculty, 21(2): 205-212.

Tudisca S., Di Trapani A.M., Sgroi F., Testa R. (2014): Economic evaluation of PDO introduction in Sicilian orange farms. Quality - Access to Success, 14: 99-103. 